\title{
Antarctic sea ice variability and trends, 1979-2010
}

\author{
C. L. Parkinson and D. J. Cavalieri \\ Cryospheric Sciences Laboratory/Code 615, NASA Goddard Space Flight Center, Greenbelt, MD 20771, USA
}

Correspondence to: C. L. Parkinson (claire.1.parkinson@nasa.gov)

Received: 14 February 2012 - Published in The Cryosphere Discuss.: 9 March 2012

Revised: 16 May 2012 - Accepted: 1 June 2012 - Published: 15 August 2012

\begin{abstract}
In sharp contrast to the decreasing sea ice coverage of the Arctic, in the Antarctic the sea ice cover has, on average, expanded since the late 1970s. More specifically, satellite passive-microwave data for the period November 1978-December 2010 reveal an overall positive trend in ice extents of $17100 \pm 2300 \mathrm{~km}^{2} \mathrm{yr}^{-1}$. Much of the increase, at $13700 \pm 1500 \mathrm{~km}^{2} \mathrm{yr}^{-1}$, has occurred in the region of the Ross Sea, with lesser contributions from the Weddell Sea and Indian Ocean. One region, that of the Bellingshausen/Amundsen Seas, has (like the Arctic) instead experienced significant sea ice decreases, with an overall ice extent trend of $-8200 \pm 1200 \mathrm{~km}^{2} \mathrm{yr}^{-1}$. When examined through the annual cycle over the 32-yr period 19792010, the Southern Hemisphere sea ice cover as a whole experienced positive ice extent trends in every month, ranging in magnitude from a low of $9100 \pm 6300 \mathrm{~km}^{2} \mathrm{yr}^{-1}$ in February to a high of $24700 \pm 10000 \mathrm{~km}^{2} \mathrm{yr}^{-1}$ in May. The Ross Sea and Indian Ocean also had positive trends in each month, while the Bellingshausen/Amundsen Seas had negative trends in each month, and the Weddell Sea and western Pacific Ocean had a mixture of positive and negative trends. Comparing ice-area results to ice-extent results, in each case the ice-area trend has the same sign as the ice-extent trend, but the magnitudes of the two trends differ, and in some cases these differences allow inferences about the corresponding changes in sea ice concentrations. The strong pattern of decreasing ice coverage in the Bellingshausen/Amundsen Seas region and increasing ice coverage in the Ross Sea region is suggestive of changes in atmospheric circulation. This is a key topic for future research.
\end{abstract}

\section{Introduction}

Sea ice spreads over millions of square kilometers of the Southern Ocean at all times of the year and over an area larger than the Antarctic continent in the midst of the austral winter, with February typically the month of minimum ice coverage and September typically the month of maximum ice coverage (Fig. 1). The ice hinders exchanges between the ocean and atmosphere, reflects solar radiation back to space, is an obstacle to ship travel, and has numerous impacts on plant and animal species in the Southern Ocean (e.g., Ainley et al., 2003; Parkinson, 2004). As an integral component of the climate system, the sea ice cover both affects and reflects changes in other climate components, hence making it of particular interest that the Antarctic sea ice cover has not experienced the prominent decreases witnessed over recent decades in the Arctic sea ice cover (Parkinson and Cavalieri, 2008; Cavalieri and Parkinson, 2008).

Unfortunately, the record of sea ice is quite incomplete for any time prior to the 1970s, due in large part to its remoteness, the harsh conditions of the polar environment, and the lack of convenient means for remotely sensing the ice at that time. In great contrast, since the late 1970s, the distribution of polar sea ice is one of the best recorded of all climate variables. The reason is the ease of distinguishing sea ice from liquid water in satellite passive-microwave observations (e.g., Zwally et al., 1983) and the near-continuous presence of at least one operating satellite passive-microwave instrument over almost the entire period since October 1978.

Through satellite passive-microwave observations, there now exists a solid record of the distribution and extent of Arctic and Antarctic sea ice coverage and their changes since the late 1970s. This record has allowed persuasive quantification of an overall decreasing Arctic sea ice coverage (e.g., Parkinson et al., 1999; Meier et al., 2007), as expected in light 

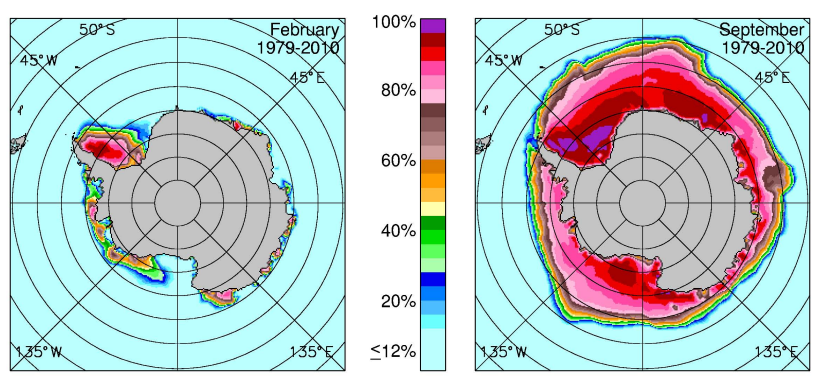

Fig. 1. Maps of Southern Hemisphere February and September sea ice concentrations, averaged over the years 1979-2010, as derived from SMMR, SSMI, and SSMIS satellite observations.

of Arctic warming (ACIA, 2005), and, at a markedly lesser rate, a less expected increasing Antarctic sea ice coverage (e.g., Stammerjohn and Smith, 1997; Zwally et al., 2002). In 2008, these trends were detailed regionally and hemispherically for the period November 1978 through December 2006 by Parkinson and Cavalieri (2008) for the Arctic and by Cavalieri and Parkinson (2008) for the Antarctic. With four additional years of data analyzed, we are now updating those results through 2010, doing so for the Antarctic in this paper and for the Arctic in a companion paper (Cavalieri and Parkinson, 2012).

\section{Data}

This study is based on satellite passive-microwave data from the Scanning Multichannel Microwave Radiometer (SMMR) on NASA's Nimbus 7 satellite, the Special Sensor Microwave Imager (SSMI) on the F8, F11, and F13 satellites of the Department of Defense's Defense Meteorological Satellite Program (DMSP), and the Special Sensor Microwave Imager Sounder (SSMIS) on the DMSP F17 satellite. Nimbus 7 was launched in late October 1978, and the SMMR instrument obtained data every other day for most of the period from 26 October 1978 through 20 August 1987. The first SSMI was launched on the DMSP F8 satellite in June 1987, and the sequence of F8, F11, and F13 SSMIs collected data on a daily basis for most of the period from 9 July 1987 to the end of 2007, after which the F13 SSMI began to degrade. The F17 SSMIS was the second SSMIS in orbit and was launched in November 2006, with a daily data record beginning in mid-December 2006. In this paper, we use SMMR data for the period November 1978-July 1987, SSMI data for August 1987-December 2007, and SSMIS data for January 2008-December 2010. These data are archived at and available from the National Snow and Ice Data Center (NSIDC) in Boulder, Colorado.

The SMMR, SSMI, and SSMIS data are used to calculate ice concentrations (percent areal coverages of ice) with the NASA Team algorithm (Gloersen et al., 1992; Cavalieri et al., 1995), and the ice concentrations are mapped at a grid cell size of $25 \times 25 \mathrm{~km}$. These ice concentrations are then used to calculate sea ice extents (summed areas of all grid cells in the region of interest having at least $15 \%$ sea ice concentration) and sea ice areas (summed products of the grid cell areas times the ice concentrations for all grid cells in the region of interest having at least $15 \%$ sea ice concentration). Details on the merging of the SMMR and SSMI records can be found in Cavalieri et al. (1999), and details on the merging of the SSMI and SSMIS records, taking advantage of the full year of data overlap in 2007, can be found in Cavalieri et al. (2012). Explanation for the $15 \%$ threshold can be found in Parkinson and Cavalieri (2008).

Ice extents and ice areas were averaged for each day of available data, with missing data filled in by spatial and temporal interpolation, and these daily averages were combined to monthly, seasonal, and yearly averages. To obtain longterm trends for the monthly results, the seasonal cycle was removed by creating monthly deviations, which were calculated by subtracting from each individual monthly average the 32-yr average for that month (or, in the case of November and December, the 33-yr average). This follows the procedure in Parkinson et al. (1999) and subsequent works.

Lines of linear least squares fit were calculated for the monthly deviation data and for the yearly, seasonal, and monthly averages. Standard deviations of the slopes of these lines were calculated based on Taylor (1997), and a rough indication of whether the trends are statistically significant as non- 0 was determined by calculating the ratio $R$ of the trend to its standard deviation, identifying a trend as significant at a $95 \%$ confidence level if $R$ exceeds 2.04 and significant at a $99 \%$ confidence level if $R$ exceeds 2.75 . This is essentially using a two-tailed t-test with 30 degrees of freedom (2 less than the number of years). It gives a useful suggestion of the relative significance of the slopes, although, like other tests of statistical significance, is imperfect in its application to the real world (e.g., Santer et al., 2000), where the assumptions underlying the tests are rarely satisfied in full.

As in Cavalieri and Parkinson (2008) and earlier studies, results are presented for the following five regions of the Southern Ocean: Weddell Sea $\left(60^{\circ} \mathrm{W}-20^{\circ} \mathrm{E}\right.$, plus the small ocean area between the east coast of the Antarctic Peninsula and $\left.60^{\circ} \mathrm{W}\right)$, Indian Ocean (20-90 $\left.{ }^{\circ} \mathrm{E}\right)$, western Pacific Ocean $\left(90-160^{\circ} \mathrm{E}\right)$, Ross Sea $\left(160^{\circ} \mathrm{E}-130^{\circ} \mathrm{W}\right)$, and the combined Bellingshausen and Amundsen Seas (130-60 W) (Fig. 2).

\section{Results}

\subsection{Sea ice extents}

\subsubsection{Southern Hemisphere total}

Figure 3 presents plots of Southern Hemisphere monthly average sea ice extents and monthly deviations for the period November 1978-December 2010 and yearly and seasonal 


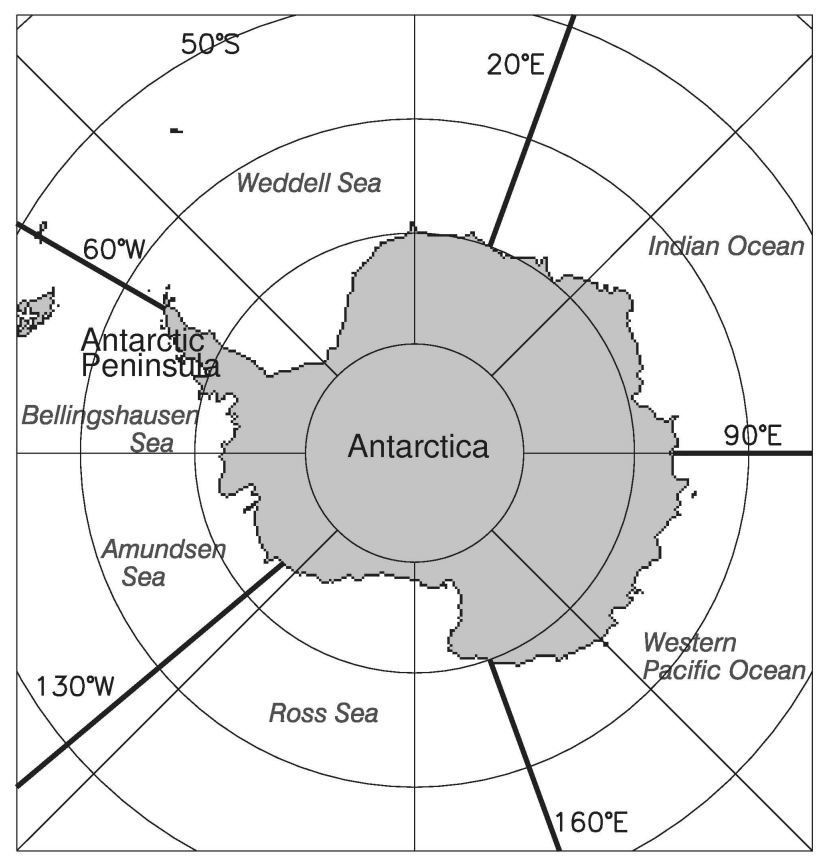

Fig. 2. Location map, including the identification of the five regions used for the sea ice analyses.

averages for 1979-2010. On average over the 32-yr period, the ice extents ranged from a minimum of $3.1 \times 10^{6} \mathrm{~km}^{2}$ in February to a maximum of $18.5 \times 10^{6} \mathrm{~km}^{2}$ in September (Fig. 3a inset).

In view of the large seasonal cycle, the plot of monthly averages is dominated by this cycle (Fig. 3a). However, when the seasonal cycle is removed, in the monthly deviations, the existence of an upward trend becomes clear, with a positive slope of $17100 \pm 2300 \mathrm{~km}^{2} \mathrm{yr}^{-1}$, statistically significant at the $99 \%$ confidence level, for the period November 1978-December 2010 (Fig. 3b). This slope has increased from the $11100 \pm 2600 \mathrm{~km}^{2} \mathrm{yr}^{-1}$ trend reported by Cavalieri and Parkinson (2008) for the monthly deviations for the shorter period November 1978-December 2006, and indeed the highest deviations in the 32-yr record are within the newly added last $4 \mathrm{yr}$ of the data set (Fig. 3b).

The slopes of the lines of linear least squares fit through the yearly and seasonal ice extent values plotted in Fig. 3c, for the Southern Hemisphere total, are presented in Table 1, as are the corresponding slopes for each of the five analysis regions. For the yearly averages, the Southern Hemisphere slope is $17500 \pm 4100 \mathrm{~km}^{2} \mathrm{yr}^{-1}\left(1.5 \pm 0.4 \% \mathrm{decade}^{-1}\right)$ (Table 1), increased from a slope of $11500 \pm 4600 \mathrm{~km}^{2} \mathrm{yr}^{-1}$ for the shorter period ending in December 2006 (Cavalieri and Parkinson, 2008) and within $3 \%$ of the slope for the monthly deviations, which have a somewhat smaller slope in part because of including at the start of the record the initial months of November and December 1978, both of which have ice extent values above the line of least squares fit (Fig. 3b). The
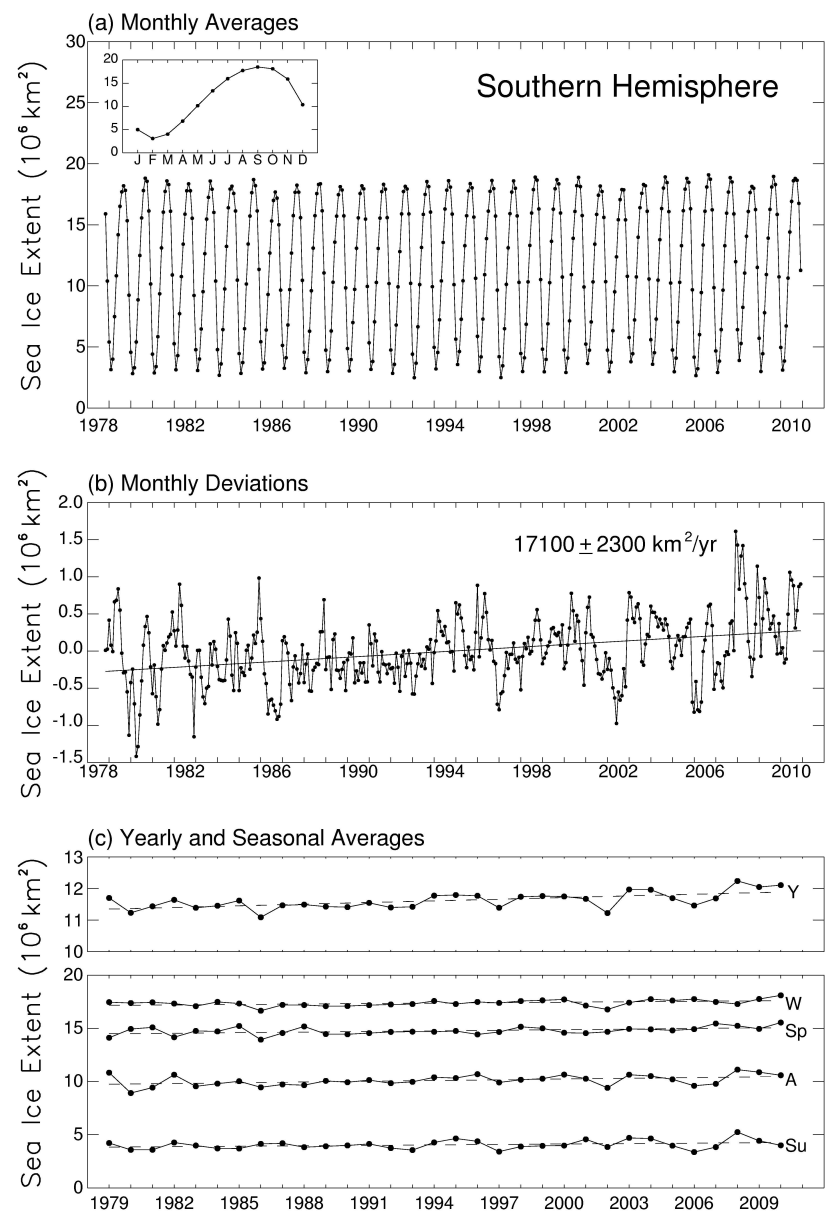

Fig. 3. (a) Monthly average Southern Ocean sea ice extents for November 1978 through December 2010, with an inset showing the average annual cycle, calculated from SMMR, SSMI, and SSMIS satellite data. (b) Monthly deviations for the sea ice extents of part a, with the line of least squares fit through the data points and its slope and standard deviation. (c) Yearly (Y) and seasonally averaged sea ice extents, 1979-2010, with the corresponding lines of least squares fit. The summer $(\mathrm{Su})$, autumn $(\mathrm{A})$, winter $(\mathrm{W})$, and spring (Sp) values cover the periods January-March, April-June, July-September, and October-December, respectively.

much higher standard deviation for the slope of the yearly averages versus the slope of the monthly deviations reflects the far smaller number of data points ( $32 \mathrm{yr}$ versus 386 months).

Seasonally, the slopes for all four seasons are positive, with the largest slope being for autumn, at $23500 \pm 8900 \mathrm{~km}^{2} \mathrm{yr}^{-1}$, and the smallest slope being for summer, at $13800 \pm 7700 \mathrm{~km}^{2} \mathrm{yr}^{-1}$ (Table 1). For every season, the slopes have increased with the addition of the 20072010 data (Table 1 versus Cavalieri and Parkinson, 2008). On a percent per decade basis, the largest seasonal slope is for summer, at $3.6 \pm 2.0 \% \mathrm{decade}^{-1}$ (Table 1). 
Table 1. Slopes and standard deviations of the lines of least squares fit for the yearly and seasonal sea ice extents in the Southern Hemisphere as a whole and in each of the five regions delineated in Fig. 2, for the period 1979-2010. $R$ is the ratio of the magnitude of the slope to the standard deviation; in the $R$ column, bold indicates statistical significance of $95 \%$ and above, and the combination of bold and italics indicates statistical significance of $99 \%$ and above.

\begin{tabular}{|c|c|c|c|c|c|c|c|c|c|}
\hline \multirow[b]{2}{*}{ Region } & \multicolumn{3}{|c|}{ Yearly } & \multicolumn{3}{|c|}{ Summer } & \multicolumn{3}{|c|}{ Autumn } \\
\hline & $10^{3} \mathrm{~km}^{2} \mathrm{yr}^{-1}$ & $R$ & $\%$ decade $^{-1}$ & $10^{3} \mathrm{~km}^{2} \mathrm{yr}^{-1}$ & $R$ & $\%$ decade $^{-1}$ & $10^{3} \mathrm{~km}^{2} \mathrm{yr}^{-1}$ & $R$ & $\%$ decade $^{-1}$ \\
\hline Southern Hemisphere & $17.5 \pm 4.1$ & 4.28 & $1.5 \pm 0.4$ & $13.8 \pm 7.7$ & 1.79 & $3.6 \pm 2.0$ & $23.5 \pm 8.9$ & 2.63 & $2.4 \pm 0.9$ \\
\hline Weddell Sea & $5.2 \pm 4.5$ & 1.17 & $1.2 \pm 1.1$ & $12.6 \pm 5.7$ & 2.21 & $9.3 \pm 4.2$ & $10.1 \pm 6.2$ & 1.64 & $2.9 \pm 1.8$ \\
\hline Indian Ocean & $5.8 \pm 2.2$ & 2.59 & $3.2 \pm 1.2$ & $2.6 \pm 1.6$ & 1.62 & $9.2 \pm 5.7$ & $5.0 \pm 2.9$ & 1.75 & $4.1 \pm 2.3$ \\
\hline Western Pacific Ocean & $0.6 \pm 1.8$ & 0.32 & $0.5 \pm 1.5$ & $2.9 \pm 2.0$ & 1.46 & $6.7 \pm 4.6$ & $3.0 \pm 2.1$ & 1.45 & $2.8 \pm 1.9$ \\
\hline Ross Sea & $13.7 \pm 3.6$ & 3.81 & $5.2 \pm 1.4$ & $10.0 \pm 4.8$ & 2.08 & $10.9 \pm 5.3$ & $14.5 \pm 5.1$ & 2.85 & $5.7 \pm 2.0$ \\
\hline Bellingshausen /Amundsen Seas & $-7.8 \pm 2.5$ & 3.17 & $-5.1 \pm 1.6$ & $-14.3 \pm 2.6$ & 5.57 & $-16.5 \pm 3.0$ & $-9.2 \pm 3.4$ & 2.70 & $-6.7 \pm 2.5$ \\
\hline
\end{tabular}

\begin{tabular}{lrrrrrr} 
& \multicolumn{3}{c}{ Winter } & \multicolumn{3}{c}{ Spring } \\
Region & $10^{3} \mathrm{~km}^{2} \mathrm{yr}^{-1}$ & $R$ & $\% \mathrm{decade}^{-1}$ & $10^{3} \mathrm{~km}^{2} \mathrm{yr}^{-1}$ & $R$ & $\% \mathrm{decade}^{-1}$ \\
\hline Southern Hemisphere & $14.2 \pm 5.1$ & $\mathbf{2 . 8 1}$ & $0.8 \pm 0.3$ & $18.6 \pm 6.2$ & 2.98 & $1.3 \pm 0.4$ \\
Weddell Sea & $-0.2 \pm 6.2$ & 0.04 & $-0.0 \pm 1.0$ & $-1.3 \pm 6.6$ & 0.20 & $-0.2 \pm 1.2$ \\
Indian Ocean & $6.5 \pm 3.9$ & 1.66 & $2.1 \pm 1.3$ & $9.1 \pm 4.1$ & $\mathbf{2 . 2 4}$ & $3.5 \pm 1.6$ \\
Western Pacific Ocean & $-1.9 \pm 3.1$ & 0.63 & $-1.1 \pm 1.7$ & $-1.6 \pm 2.6$ & 0.61 & $-1.1 \pm 1.8$ \\
Ross Sea & $12.5 \pm 4.5$ & $\mathbf{2 . 7 9}$ & $3.3 \pm 1.2$ & $17.6 \pm 5.1$ & $\mathbf{3 . 4 8}$ & $5.5 \pm 1.6$ \\
Bellingshausen/Amundsen Seas & $-2.6 \pm 4.1$ & 0.65 & $-1.2 \pm 1.9$ & $-5.2 \pm 4.6$ & 1.12 & $-2.9 \pm 2.6$ \\
\hline
\end{tabular}

\subsubsection{Regional results}

Figure 4 presents monthly deviation plots for each of the five Antarctic sea ice analysis regions of Fig. 2, as well as for the total. For this five-part regional sectoring, the western Pacific Ocean shows no significant trend, the Weddell Sea, Indian Ocean, and Ross Sea all have positive trends, and the Bellingshausen/Amundsen Seas region has a negative trend, with the highest magnitude trend being the $13700 \pm 1500 \mathrm{~km}^{2} \mathrm{yr}^{-1}$ positive trend for the Ross Sea and the second highest magnitude trend being the $-8200 \pm 1200 \mathrm{~km}^{2} \mathrm{yr}^{-1}$ negative trend for the Bellingshausen/Amundsen Seas (Fig. 4). The trends for the Ross Sea, Bellingshausen/Amundsen Seas, and Indian Ocean are all statistically significant at the $99 \%$ confidence level, while the trend for the Weddell Sea is statistically significant at the $95 \%$ confidence level.

The Ross Sea has positive trends in each season, with its highest seasonal trend being in spring, at $17600 \pm 5100 \mathrm{~km}^{2} \mathrm{yr}^{-1}$, and its lowest seasonal trend being in summer, at $10000 \pm 4800 \mathrm{~km}^{2} \mathrm{yr}^{-1}$ (Table 1). In the opposite direction, the Bellingshausen/Amundsen Seas region has negative trends in each season, ranging in magnitude from $-2600 \pm 4100 \mathrm{~km}^{2} \mathrm{yr}^{-1}$ in winter to $-14300 \pm 2600 \mathrm{~km}^{2} \mathrm{yr}^{-1}$ in summer (Table 1). Like the Ross Sea, the Indian Ocean has positive ice extent trends in each season, although the magnitudes are consistently lower than those in the Ross Sea, both on a $\mathrm{km}^{2} \mathrm{yr}^{-1}$ basis and on a $\%$ decade $^{-1}$ basis. The Weddell Sea and western Pacific Ocean both have small, statistically insignificant negative trends in winter and spring and higher magnitude positive trends in summer and autumn, with positive but statistically insignificant trends for the yearly averages (Table 1).
On a monthly basis, the Ross Sea has positive trends of at least $7000 \mathrm{~km}^{2} \mathrm{yr}^{-1}$ in each month, and the Indian Ocean has positive trends in each month, although consistently of lesser magnitude than those in the Ross Sea (Fig. 5). The Bellingshausen/Amundsen Seas region has negative trends in each month, although much more so in summer than in winter; the Weddell Sea has positive trends for each month January-June and a mixture of positive and negative trends for the rest of the year, with near-0 values in July, August, and September. The western Pacific Ocean has positive trends in the first half of the year and predominantly negative trends in the second half, although with no trend of magnitude as high as $5000 \mathrm{~km}^{2} \mathrm{yr}^{-1}$ (Fig. 5). The net result is a Southern Hemisphere sea ice cover with positive 32-yr sea ice extent trends in every month of the year, ranging in magnitude from a low of $9100 \pm 6300 \mathrm{~km}^{2} \mathrm{yr}^{-1}$ in February to a high of $24700 \pm 10000 \mathrm{~km}^{2} \mathrm{yr}^{-1}$ in May (Fig. 5).

\subsection{Sea ice areas}

\subsubsection{Southern Hemisphere total}

Figures 6-8 and Table 2 present for sea ice areas the corresponding information to what is presented in Figs. 3-5 and Table 1 for ice extents. In all instances, ice areas are necessarily lower than or equal to ice extents, with equality only coming in cases of no ice cover or complete, $100 \%$ ice coverage.

The hemispheric ice area monthly averages (Fig. 6a) show the same basic seasonal cycle as the ice extent monthly averages (Fig. 3a), although with lower values. For the ice areas, the 32-yr average seasonal cycle has values ranging from $2.0 \times 10^{6} \mathrm{~km}^{2}$ in February to $14.6 \times 10^{6} \mathrm{~km}^{2}$ in September (Fig. 6a inset). The ice area monthly deviation 

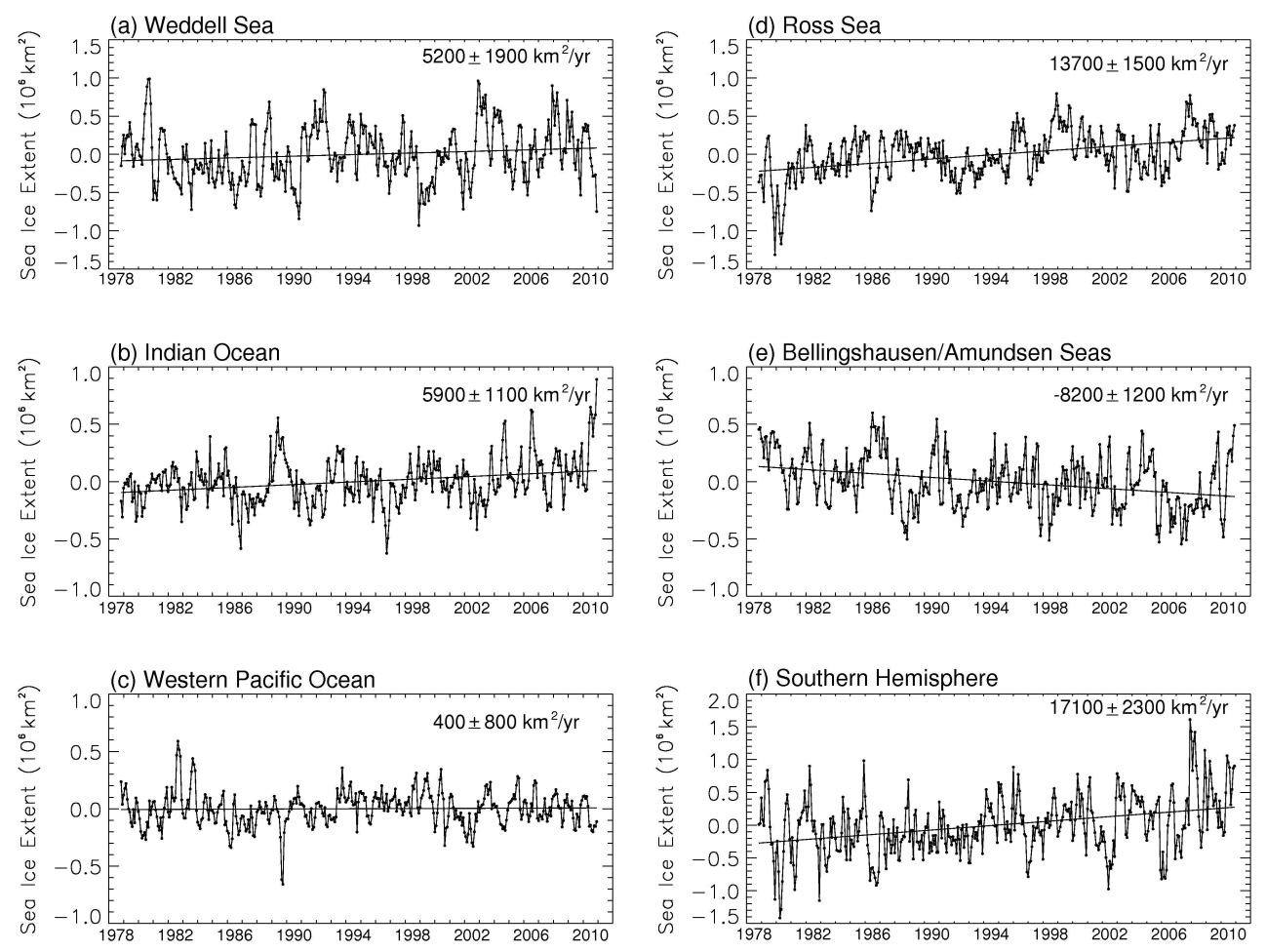

Fig. 4. Sea ice extent monthly deviation plots, November 1978 through December 2010, calculated from SMMR, SSMI, and SSMIS satellite data, for the following regions and hemispheric total: (a) Weddell Sea, (b) Indian Ocean, (c) western Pacific Ocean, (d) Ross Sea, (e) Bellingshausen/Amundsen Seas, and (f) Southern Hemisphere as a whole.

plot has some visually noticeable differences from the ice extent monthly deviation plot, and the slope of the ice area trend line is somewhat lower than that for the ice extents, being $14900 \pm 2100 \mathrm{~km}^{2} \mathrm{yr}^{-1}$ (Fig. 6b versus Fig. 3b). As is the case for ice extents, the last $4 \mathrm{yr}$ of the data set contain within them the highest monthly deviations of the entire data set, with the result that the ice area trend has increased over the $9600 \pm 2400 \mathrm{~km}^{2} \mathrm{yr}^{-1}$ trend reported in Cavalieri and Parkinson (2008) for November 1978-December 2006.

As with the ice extents, the sea ice area trends for the Southern Hemisphere are positive in each season and for the yearly average, with the highest magnitude ice area seasonal trend being for autumn, at $25800 \pm 8300 \mathrm{~km}^{2} \mathrm{yr}^{-1}$ (Table 2). The lowest magnitude seasonal trend for ice areas, however, is for spring rather than for summer (Table 2 versus Table 1). Furthermore, for summer, winter, and spring, the ice area trend has lower magnitude than the ice extent trend, whereas for autumn the ice area trend has higher magnitude than the ice extent trend (Tables 1 and 2). The autumn situation, with ice area increasing faster than ice extent, implies that the autumn ice cover had a trend toward increasing ice concentration overall for the 1979-2010 period. On a \% decade ${ }^{-1}$ basis, the greatest seasonal ice area slope is for summer, at $4.6 \pm 2.4 \%$ decade $^{-1}$ (Table 2).

\subsubsection{Regional results}

Regionally, the basic qualitative results remain largely the same for ice areas as for ice extents. Specifically, the 32-yr ice area monthly deviation trends are positive for the Weddell Sea, Indian Ocean, and Ross Sea, and are negative for the Bellingshausen/Amundsen Seas, with the highest magnitude slope being the positive slope for the Ross Sea and the second highest magnitude slope being the negative slope for the Bellingshausen/Amundsen Seas (Fig. 7). One difference is that the positive slope for the ice area monthly deviations for the western Pacific Ocean is statistically significant at the $95 \%$ level, versus the statistically insignificant positive slope for the ice extent monthly deviations. The western Pacific Ocean, which has by far the lowest of the six slopes in both the ice area and ice extent cases, is the only one of the five regions that has a higher slope for the ice area monthly deviations than for the ice extent monthly deviations (Figs. 4 and 7).

Monthly trends for ice areas (Fig. 8) also show many similarities with the monthly trends for ice extents (Fig. 5), including positive trends for every month for the Indian Ocean and Ross Sea and negative trends (some near 0) for every month for the Bellingshausen/Amundsen Seas. The magnitudes differ, however, with generally lower magnitude ice area slopes (versus ice extent slopes) in the Ross Sea, Indian 

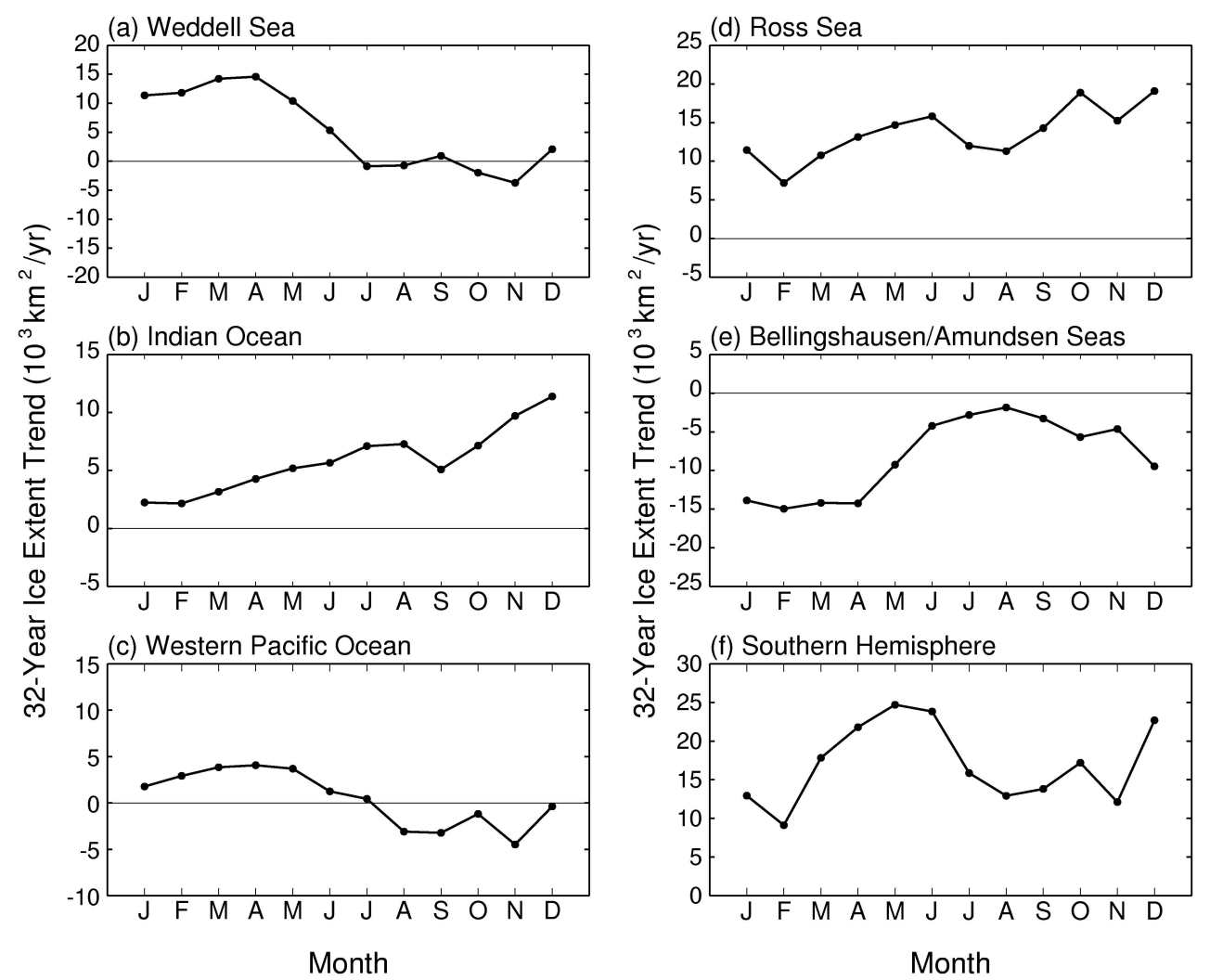

Fig. 5. Monthly sea ice extent trends, 1979-2010, for the following regions and hemispheric total: (a) Weddell Sea, (b) Indian Ocean, (c) western Pacific Ocean, (d) Ross Sea, (e) Bellingshausen/Amundsen Seas, and (f) Southern Hemisphere as a whole.

Table 2. Slopes and standard deviations of the lines of least squares fit for the yearly and seasonal sea ice areas in the Southern Hemisphere as a whole and in each of the five regions delineated in Fig. 2, for the period 1979-2010. $R$ is the ratio of the magnitude of the slope to the standard deviation; in the $R$ column, bold indicates statistical significance of $95 \%$ and above, and the combination of bold and italics indicates statistical significance of $99 \%$ and above.

\begin{tabular}{|c|c|c|c|c|c|c|c|c|c|}
\hline \multirow[b]{2}{*}{ Region } & \multicolumn{3}{|c|}{ Yearly } & \multicolumn{3}{|c|}{ Summer } & \multicolumn{3}{|c|}{ Autumn } \\
\hline & $10^{3} \mathrm{~km}^{2} \mathrm{yr}^{-1}$ & $R$ & $\%$ decade $^{-1}$ & $10^{3} \mathrm{~km}^{2} \mathrm{yr}^{-1}$ & $R$ & $\%$ decade $^{-1}$ & $10^{3} \mathrm{~km}^{2} \mathrm{yr}^{-1}$ & $R$ & $\%$ decade $^{-1}$ \\
\hline Southern Hemisphere & $15.3 \pm 3.4$ & 4.44 & $1.8 \pm 0.4$ & $11.4 \pm 5.8$ & 1.95 & $4.6 \pm 2.4$ & $25.8 \pm 8.3$ & 3.11 & $3.5 \pm 1.1$ \\
\hline Weddell Sea & $4.4 \pm 3.6$ & 1.21 & $1.3 \pm 1.1$ & $11.3 \pm 4.6$ & 2.45 & $11.7 \pm 4.8$ & $9.4 \pm 5.2$ & 1.81 & $3.3 \pm 1.8$ \\
\hline Indian Ocean & $4.2 \pm 2.0$ & 2.09 & $3.2 \pm 1.5$ & $1.5 \pm 1.1$ & 1.39 & $9.4 \pm 6.7$ & $3.9 \pm 2.5$ & 1.58 & $4.4 \pm 2.8$ \\
\hline Western Pacific Ocean & $1.4 \pm 1.3$ & 1.09 & $1.8 \pm 1.7$ & $3.0 \pm 1.5$ & 2.00 & $11.9 \pm 5.9$ & $3.6 \pm 1.7$ & 2.07 & $5.1 \pm 2.4$ \\
\hline Ross Sea & $10.9 \pm 2.9$ & 3.81 & $5.4 \pm 1.4$ & $6.3 \pm 3.2$ & 1.95 & $11.8 \pm 6.1$ & $14.1 \pm 4.5$ & 3.12 & $7.0 \pm 2.3$ \\
\hline Bellingshausen/Amundsen Seas & $-5.6 \pm 1.9$ & 2.97 & $-5.1 \pm 1.7$ & $-10.7 \pm 2.0$ & 5.31 & $-18.6 \pm 3.5$ & $-5.3 \pm 2.6$ & 2.03 & $-5.6 \pm 2.8$ \\
\hline
\end{tabular}

\begin{tabular}{lrrrrrr} 
& \multicolumn{3}{c}{ Winter } & \multicolumn{3}{c}{ Spring } \\
Region & $10^{3} \mathrm{~km}^{2} \mathrm{yr}^{-1}$ & $R$ & $\%$ decade $^{-1}$ & $10^{3} \mathrm{~km}^{2} \mathrm{yr}^{-1}$ & $R$ & $\%$ decade $^{-1}$ \\
\hline Southern Hemisphere & $13.1 \pm 4.3$ & $\mathbf{3 . 0 4}$ & $1.0 \pm 0.3$ & $11.0 \pm 6.2$ & 1.77 & $1.0 \pm 0.6$ \\
Weddell Sea & $-0.0 \pm 5.1$ & 0.00 & $-0.0 \pm 1.0$ & $-2.9 \pm 6.2$ & 0.47 & $-0.7 \pm 1.5$ \\
Indian Ocean & $5.3 \pm 3.5$ & 1.48 & $2.2 \pm 1.5$ & $6.0 \pm 3.5$ & 1.72 & $3.3 \pm 1.9$ \\
Western Pacific Ocean & $-0.6 \pm 2.5$ & 0.26 & $-0.5 \pm 2.0$ & $-0.1 \pm 1.8$ & 0.07 & $-0.1 \pm 2.0$ \\
Ross Sea & $10.0 \pm 3.9$ & $\mathbf{2 . 5 5}$ & $3.3 \pm 1.3$ & $13.2 \pm 4.1$ & $\mathbf{3 . 2 0}$ & $5.5 \pm 1.7$ \\
Bellingshausen /Amundsen Seas & $-1.5 \pm 3.2$ & 0.47 & $-1.0 \pm 2.1$ & $-5.1 \pm 3.3$ & 1.55 & $-3.9 \pm 2.5$ \\
\hline
\end{tabular}



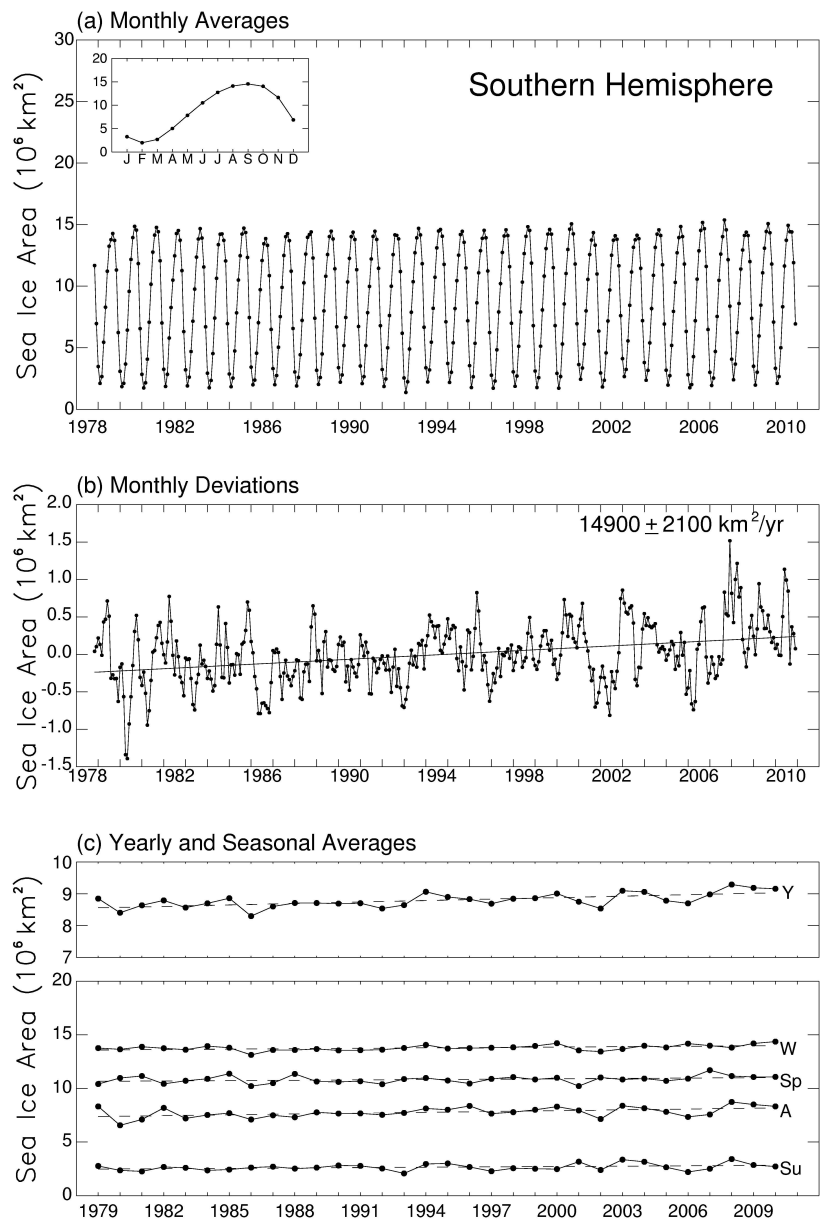

Fig. 6. Same as Fig. 3 except for ice areas instead of ice extents.

Ocean, and Bellingshausen/Amundsen Seas. The Weddell Sea and western Pacific Ocean have a more mixed pattern, both in the sign of the slope and in how the ice area and ice extent slopes differ (Figs. 5 and 8). In the western Pacific Ocean, the yearly, summer, and autumn slopes are positive with higher slopes for the ice area than the ice extent. This suggests increased ice concentration in the summer, autumn, and on a yearly average basis, although without a high level of statistical significance (Tables 1 and 2).

\section{Discussion}

The upward trends in sea ice extents and areas reported here for the Southern Hemisphere are in sharp contrast to the situation in the Arctic, where downward trends have been reported since the late 1980s (Parkinson and Cavalieri, 1989) and have become stronger over time (Johannessen et al., 1995; Parkinson et al., 1999; Meier et al., 2007; Comiso et al., 2008; Cavalieri and Parkinson, 2012). The sea ice decreases in the Arctic are readily tied to the warming that has also been reported in the Arctic and to the broader phenomenon of global warming (e.g., ACIA, 2005).

In the Antarctic case, the sea ice decreases in the region of the Bellingshausen/Amundsen Seas can also be tied to warming, as they have occurred in conjunction with marked warming in the Antarctic Peninsula/Bellingshausen Sea vicinity, likely caused (at least in part) by large-scale atmospheric circulation changes (Vaughn et al., 2003). The sea ice increases around much of the rest of the continent might similarly be aligned with overall cooling in those regions (e.g., Vaughn et al., 2003), although this is less certain, as there is considerable uncertainty about temperature trends in much of the Antarctic outside of the well-documented Peninsula region, with recent reconstructions questioning earlier results (O'Donnell et al., 2011).

Antarctic sea ice variability since the late 1970 s is welldocumented (e.g., Gloersen et al., 1992; Zwally et al., 2002; Cavalieri and Parkinson, 2008) and has been examined in connection with other Earth-system phenomena, such as the El Niño-Southern Oscillation (ENSO) (e.g., Simmonds and Jacka, 1995; Watkins and Simmonds, 2000; Rind et al., 2001; Kwok and Comiso, 2002; Yuan, 2004; Stammerjohn et al., 2008) and the Southern Annular Mode (SAM) (e.g., Hall and Visbeck, 2002; Thompson and Solomon, 2002; Goose et al., 2008; Stammerjohn et al., 2008; Comiso et al., 2011). Rind et al. (2001) suggest less sea ice in the Pacific and more sea ice in the Weddell Sea in an El Niño year, and vice versa in a La Niña year.

Of particular interest are the studies that address the observed pattern of negative sea ice trends in the Bellingshausen Sea and positive sea ice trends in the Ross Sea (Figs. 4 and 7). For instance, Stammerjohn et al. (2008) find that, at least over the period of their study (1979-2004), this pattern appears associated with decadal changes in the mean state of the SAM and the response of the sea ice cover to the ENSO, with the response being particularly strong when an El Niño occurred with a negative SAM index and when a La Niña occurred with a positive SAM index. Notably, however, the connections between sea ice and the ENSO and SAM are "not as consistent over time" in the other regions of the Antarctic sea ice cover (Stammerjohn et al., 2008).

Thompson and Solomon (2002) explain the warming of the Antarctic Peninsula region and the apparent cooling of much of the rest of Antarctica by connection with a trend toward a strengthened circumpolar flow in the summer and fall, with the tropospheric trends traced to trends in the polar vortex of the lower stratosphere. As these latter trends are thought to be largely due to Antarctic ozone depletion, this creates a possible connection between the pattern of sea ice changes and human-caused stratospheric ozone depletion (Thompson and Solomon, 2002). Shindell and Schmidt (2004) also connect the cooling over much of Antarctica to ozone changes and the SAM, but they do not 

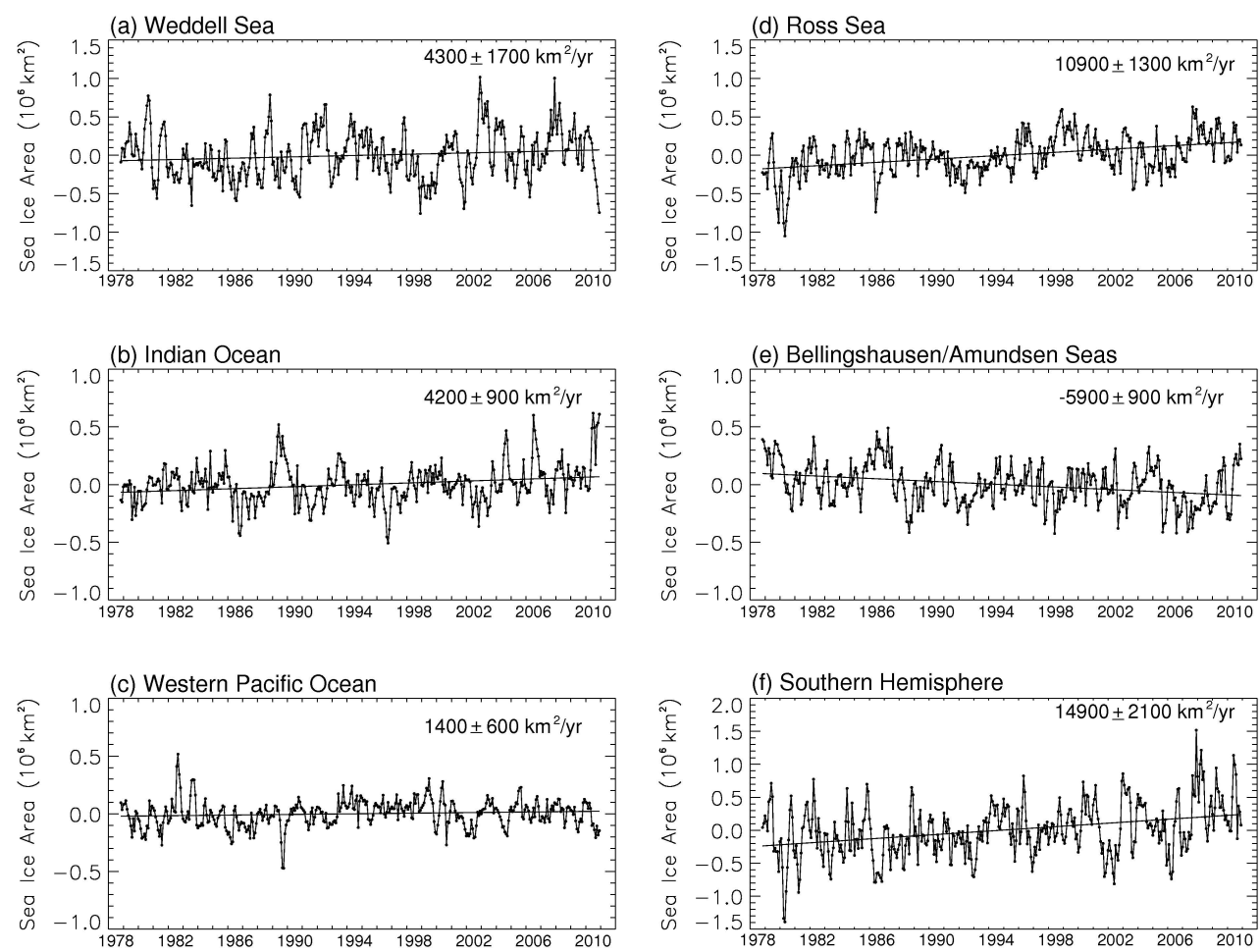

Fig. 7. Same as Fig. 4 except for ice areas instead of ice extents.
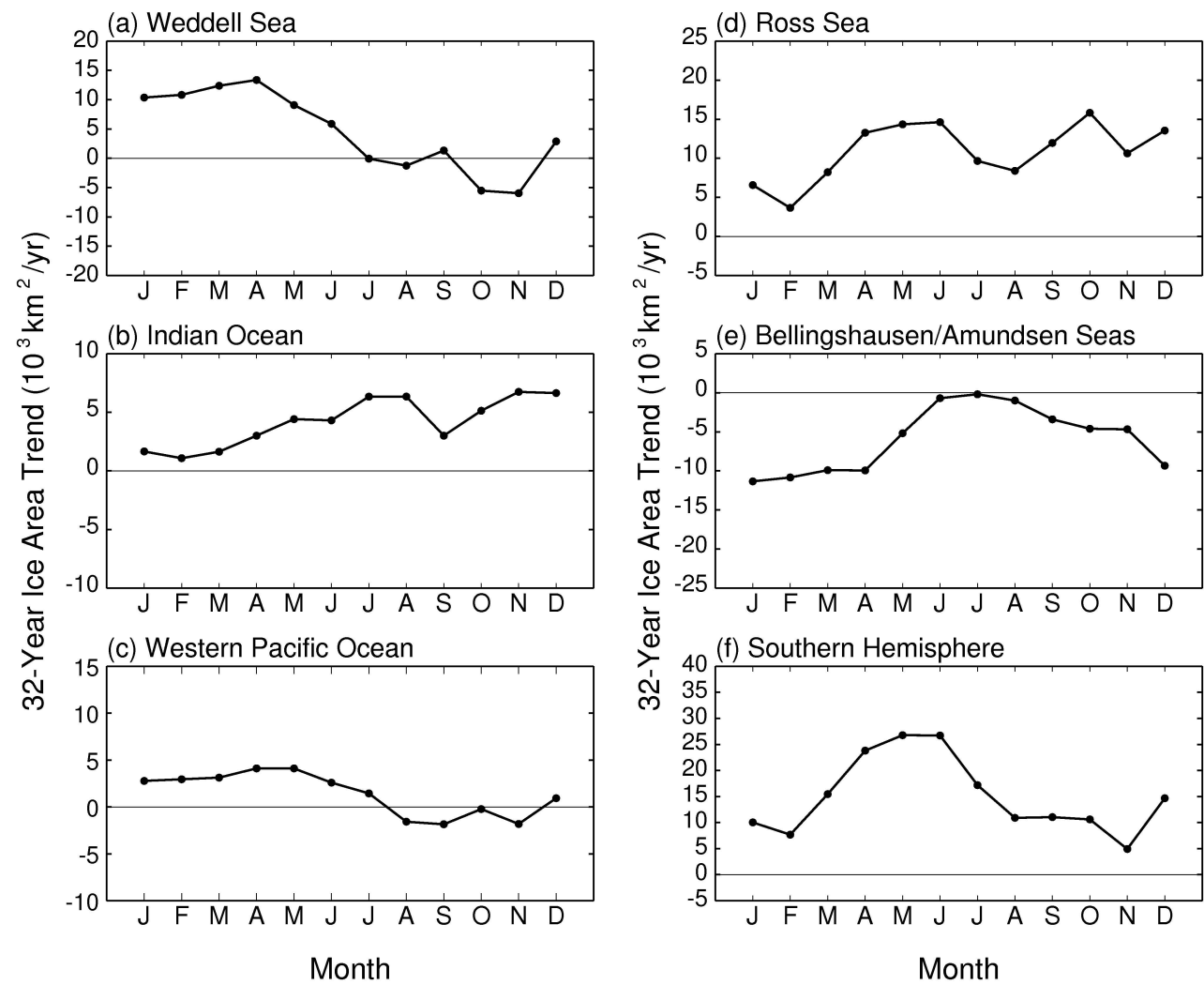

Fig. 8. Same as Fig. 5 except for ice areas instead of ice extents. 
explicitly further connect these changes to the pattern of sea ice changes.

In a paper focused on the contrast between the sea ice decreases in the Bellingshausen/Amundsen Seas and increases in the Ross Sea (as in Figs. 4 and 7), Turner et al. (2009) also, like Thompson and Solomon (2002), tie this pattern to stratospheric ozone depletion. In the Turner et al. (2009) paper, a key mechanism is increased cyclonic atmospheric flow over the Amundsen Sea, bringing warm air from the north over the Bellingshausen Sea and cold air from the south over the Ross Sea. Increased cyclonic flow would indeed thereby provide a persuasive explanation of the pattern of sea ice changes. Connecting the increased cyclonic flow to the human-caused ozone depletion is model-based and less certain. The paper concludes that "the observed sea ice increase might still be within the range of natural climate variability" (Turner et al., 2009).

In a modeling study specifically addressing the issue of whether the ozone hole has contributed to increased Antarctic sea ice extent, Sigmond and Fyfe (2010) conclude that it has not. In fact, their climate model simulates that stratospheric ozone depletion would lead to a decrease in Antarctic sea ice, and hence they conclude that the observed increase in Antarctic sea ice extent must be caused by something other than ozone depletion.

In sum, while the changes in sea ice extent and area in the Antarctic since the late 1970s are well documented, both hemispherically (Figs. 3 and 6) and regionally (Figs. 4, 5, 7, and 8), through satellite observations, their causes are not yet fully understood. The Earth's climate system is notably complex, with numerous nonlinear feedbacks; and hence climate change is continually inducing varied responses in different regions. Fortunately, the observational data base continues to grow, and models and data analyses continue to mature, so that eventually the connections between the changes in the Antarctic sea ice coverage and the changes in the rest of the global system (atmosphere, oceans, land, ice, and biosphere) should be explained, as future studies reveal more of the details of the ongoing Earth-system changes and their interconnections.

Acknowledgements. The authors thank Nick DiGirolamo of Science Systems and Applications Incorporated (SSAI) and Al Ivanoff of ADNET Systems for considerable help in processing the data and Nick DiGirolamo additionally for help in generating the figures. We also thank the National Snow and Ice Data Center (NSIDC) for providing the DMSP SSMI and SSMIS daily gridded brightness temperatures. This work was supported with muchappreciated funding from NASA's Cryospheric Sciences Program.

Edited by: E. Hanna

\section{References}

ACIA: Arctic Climate Impact Assessment, Cambridge, UK, Cambridge University Press, 1042 pp., 2005.

Ainley, D. G., Tynan, C. T., and Stirling, I.: Sea ice: A critical habitat for polar marine mammals and birds, in: Sea Ice: An Introduction to Its Physics, Chemistry, Biology, and Geology, edited by: Thomas, D. N. and Dieckmann, G. S., Oxford, Blackwell Science, 240-266, 2003.

Cavalieri, D. J. and Parkinson, C. L.: Antarctic sea ice variability and trends, 1979-2006, J. Geophys. Res., 113, C07004, doi:10.1029/2007JC004564, 2008.

Cavalieri, D. J. and Parkinson, C. L.: Arctic sea ice variability and trends, 1979-2010, The Cryosphere, 6, 881-889, doi:10.5194/tc6-881-2012, 2012.

Cavalieri, D. J., St. Germain, K., and Swift, C. T.: Reduction of weather effects in the calculation of sea ice concentration with the DMSP SSM/I, J. Glaciol., 44, 455-464, 1995.

Cavalieri, D. J., Parkinson, C. L., Gloersen, P., Comiso, J. C., and Zwally, H. J.: Deriving long-term time series of sea ice cover from satellite passive-microwave multisensor data sets, J. Geophys. Res., 104, 15803-15814, 1999.

Cavalieri, D. J., Parkinson, C. L., DiGirolamo, N., and Ivanoff, A.: Intersensor calibration between F13 SSMI and F17 SSMIS for global sea ice data records, IEEE Geosci. Remote Sensing Lett., 9, 233-236, 2012.

Comiso, J. C., Parkinson, C. L., Gersten, R., and Stock, L.: Accelerated decline in the Arctic sea ice cover, Geophys. Res. Lett., 35, L01703, doi:10.1029/2007GL031972, 2008.

Comiso, J. C., Kwok, R., Martin, S., and Gordon, A. L.: Variability and trends in sea ice extent and ice production in the Ross Sea, J. Geophys. Res., 116, C04021, doi:10.1029/2010JC006391, 2011.

Gloersen, P., Campbell, W. J., Cavalieri, D. J., Comiso, J. C., Parkinson, C. L., and Zwally, H. J.: Arctic and Antarctic Sea Ice, 19781987: Satellite Passive-Microwave Observations and Analysis, Washington, DC, National Aeronautics and Space Administration, 290 pp., 1992.

Goosse, H., Lefebvre, W., de Montety, A., Crespin, E., and Orsi, A. H.: Consistent past half-century trends in the atmosphere, the sea ice and the ocean at high southern latitudes, Clim. Dynam., 33, 999-1016, doi:10.1007/s00382-008-0500-9, 2008.

Hall, A. and Visbeck, M.: Synchronous variability in the Southern Hemisphere atmosphere, sea ice, and ocean resulting from the Annular Mode, J. Climate, 15, 3043-3057, 2002.

Johannessen, O. M., Miles, M., and Bjørgo, E.: The Arctic's shrinking sea ice, Nature, 376, 126-127, doi:10.1038/376126a0, 1995.

Kwok, R. and Comiso, J. C.: Southern Ocean climate and sea ice anomalies associated with the Southern Oscillation, J. Climate, 15, 487-501, 2002.

Meier, W. N., Stroeve, J., and Fetterer, F.: Whither Arctic sea ice? A clear signal of decline regionally, seasonally and extending beyond the satellite record, Ann. Glaciol., 46, 428-434, 2007.

O’Donnell, R., Lewis, N., McIntyre, S., and Condon, J.: Improved methods for PCA-based reconstruction: Case study using the Steig et al. (2009) Antarctic temperature reconstructions, J. Climate, 24, 2099-2115, 2011.

Parkinson, C. L.: Southern Ocean sea ice and its wider linkages: Insights revealed from models and observations, Antarctic Science, 16, 4, 387-400, doi:10.1017/S0954102004002214, 2004. 
Parkinson, C. L. and Cavalieri, D. J.: Arctic sea ice 1973-1987: Seasonal, regional, and interannual variability, J. Geophys. Res., 94, 14499-14523, 1989.

Parkinson, C. L. and Cavalieri, D. J.: Arctic sea ice variability and trends, 1979-2006, J. Geophys. Res., 113, C07003, doi:10.1029/2007JC004558, 2008.

Parkinson, C. L., Cavalieri, D. J., Gloersen, P., Zwally, H. J., and Comiso, J. C.: Arctic sea ice extents, areas, and trends, 19781996, J. Geophys. Res., 104, 20837-20856, 1999.

Rind, D., Chandler, M., Lerner, J., Martinson, D. G., and Yuan, X.: Climate response to basin-specific changes in latitudinal temperature gradients and implications for sea ice variability, J. Geophys. Res., 106, 20161-20173, 2001.

Santer, B. D., Wigley, T. M. L., Boyle, J. S., Gaffen, D. J., Hnilo, J. J., Nychka, D., Parker, D. E., and Taylor, K. E.: Statistical significance of trends and trend differences in layer-average atmospheric temperature time series, J. Geophys. Res., 105, 73377356, doi:10.1029/1999JD901105, 2000.

Shindell, D. T. and Schmidt, G. A.: Southern Hemisphere climate response to ozone changes and greenhouse gas increases, Geophys. Res. Lett., 31, L18209, doi:10.1029/2004GL020724, 2004.

Sigmond, M. and Fyfe, J. C.: Has the ozone hole contributed to increased Antarctic sea ice extent?, Geophys. Res. Lett., 37, L18502, doi:10.1029/2010GL044301, 2010.

Simmonds, I. and Jacka, T. H.: Relationships between the interannual variability of Antarctic sea ice and the Southern Oscillation, J. Climate, 8, 637-647, 1995.

Stammerjohn, S. E. and Smith, R. C.: Opposing Southern Ocean climate patterns as revealed by trends in regional sea ice coverage, Climatic Change, 37, 617-639, 1997.

Stammerjohn, S. E., Martinson, D. G., Smith, R. C., Yuan, X., and Rind, D.: Trends in Antarctic annual sea ice retreat and advance and their relation to El Niño - Southern Oscillation and Southern Annular Mode variability, J. Geophys. Res., 113, C03S90, doi:10.1029/2007JC004269, 2008.
Taylor, J. R.: Least-squares fitting, in: An Introduction to Error Analysis: The Study of Uncertainties in Physical Measurements, second edition, Sausalito, California, University Science Books, 181-207, 1997.

Thompson, D. W. J. and Solomon, S.: Interpretation of recent Southern Hemisphere climate change, Science, 296, 895-899, 2002.

Turner, J., Comiso, J. C., Marshall, G. J., Lachlan-Cope, T. A., Bracegirdle, T., Maksym, T., Meredith, M. P., Wang, Z., and Orr, A.: Non-annular atmospheric circulation change induced by stratospheric ozone depletion and its role in the recent increase of Antarctic sea ice extent, Geophys. Res. Lett., 36, L08502, doi:10.1029/2009GL037524, 2009.

Vaughan, D. G., Marshall, G. J., Connolley, W. M., Parkinson, C., Mulvaney, R., Hodgson, D. A., King, J. C., Pudsey, C. J., and Turner, J.: Recent rapid regional climate warming on the Antarctic Peninsula, Climatic Change, 60, 243-274, 2003.

Watkins, A. B. and Simmonds, I.: Current trends in Antarctic sea ice: The 1990s impact on a short climatology, J. Climate, 13, 4441-4451, 2000

Yuan, X.: ENSO-related impacts on Antarctic sea ice: A synthesis of phenomenon and mechanisms, Antarctic Science, 16, 415425, doi:10.1017/S0954102004002238, 2004.

Zwally, H. J., Comiso, J. C., Parkinson, C. L., Campbell, W. J., Carsey, F. D., and Gloersen, P.: Antarctic Sea Ice, 1973-1976: Satellite Passive-Microwave Observations, Washington, DC, National Aeronautics and Space Administration, 206 pp., 1983.

Zwally, H. J., Comiso, J. C., Parkinson, C. L., Cavalieri, D. J., and Gloersen, P.: Variability of Antarctic sea ice 1979-1998, J. Geophys. Res., 107, 3041, doi:10.1029/2000JC000733, 2002. 